\title{
SACLAY \\ NATURAL RADIOCARBON MEASUREMENTS II
}

\author{
G. DELIBRIAS, M. T. GUILLIER and J. LABEYRIE
}

Service d'Electronique Physique, Centre d'Etudes Nucléaires de Saclay

B.P. no. 2, Gif-sur-Yvette (S. et O.), France

The list of dates grouped below represents datings made during 1963. The method and the counting techniques have been previously described (Radiocarbon, v. 6, Saclay I).

Dates are obtained on the basis of the half-life given by Libby et al., 5570 yr, and the zero of the age scale is A.D. 1950. The errors given are calculated from the standard deviation of the numbers of counts totalized during a measurement of 24 hours, although each sample is measured at least twice every 24 hours.

\section{SAMPLE DESCRIPTIONS}

I. ARCHAEOLOGIC SAMPLES

\section{A. France}

\section{Sa-245. Mont Saint-Michel, Manche}

$1075 \pm 120$

Mortar from central pillar, in church Notre-Dame-sous-Terre from the Abbaye du Mont-Saint-Michel $\left(48^{\circ} 38^{\prime} \mathrm{N}\right.$ Lat, $1^{\circ} 30^{\prime} \mathrm{W}$ Long $)$. Coll. and subm. 1962 by Y. M. Froidevaux, Direction de l'Architecture des Monuments Historiques, Paris. Comment: during excavations in 1906-08, an ancient construction was discovered underground the XIth century Abbey. This early construction excavated in the upper part of the granitic island of Mont SaintMichel is dated here as Carolingian, as was expected from architectural features.

\section{Sa-230. Ile de Malvant, Morbihan $\quad 4740 \pm 300$ \\ 2790 в.c.}

Charcoal from cliff, $2.50 \mathrm{~m}$ high with top $3.50 \mathrm{~m}$ above upper present sealevel, formed with levels of aggiomerate sand separated by several levels of quartz pebbles, and overhanging a sandy shore, at Ile de Malvant also called Ile aux Chevaux ( $47^{\circ} 24^{\prime} \mathrm{N}$ Lat, $2^{\circ} 58^{\prime} \mathrm{W}$ Long) ; charcoal was in upper level of agglomerate sand, $0.70 \mathrm{~m}$ thick, mixed with kitchen remains accompanied by amphora fragments and black pottery of "Venete" type. Coll. and subm. 1962 by A. Bauer, Expéd. Glaciologiques Internat. au Groenland, Strasbourg, France.

\section{Sa-228. Thonon, Haute-Savoie}

Chestnut wood from piling buried in mud from a lacustrine "Palafte" city in harbour of Thonon, lake of Geneva $\left(46^{\circ} 20^{\prime} \mathrm{N}\right.$ Lat, $6^{\circ} 28^{\prime} \mathrm{W}$ Long), water depth $6 \mathrm{~m}, 10 \mathrm{~m}$ from $\mathrm{N}$ side of the pier. Coll. and subm. 1962 by B. Dussart, C.N.R.S., Gif-sur-Yvette (Seine et Oise). Comment: many bronze axes, knives, rings, pins have been extracted from same site. Destruction of "Palaffite" cities located on shores of lake of Geneva, by Gaulois invasion was supposed from Roman reports to have happened around 500 B.c. 


\section{Sa-227. Petite-Faye-en-Chamborand, Creuse}

$1010 \pm 120$

A.D. 840

Oak pillar from small ancient gold mine at La-Petite-Faye-en-Chamborand, Creuse $\left(46^{\circ} 7^{\prime} 36^{\prime \prime} \mathrm{N}\right.$ Lat, $1^{\circ} 47^{\prime} 30^{\prime \prime}$ E Long). Coll. and subm. 1962 by $\mathrm{J}$. Geffroy, Centre d'Etudes Nucléaires de Fontenay-aux-Roses (Seine). Comment: expected age Gallo-Roman or older. This small mine is one of 200 pit-holes in granitic Limousin province; the working began during Gaulois period and lasted till Middle Ages in some cases.

\section{Sa-204. Marseille, Bouches du Rhône}

$1710 \pm 150$

A.D. 240

Nuts found in Roman amphora, brought up from Mediterranean Sea, $30 \mathrm{~m}$ deep, off Marseille ( $43^{\circ} 18^{\prime} \mathrm{N}$ Lat, $5^{\circ} 22^{\prime}$ E Long). Subm. by J. Ranque, Faculté de Médecine de Marseille, France. Comment: many commercial Roman ships have been found on sea bottom along French Mediterranean coast, loaded with thousands of amphorae of different types. Only a few contain intact organic remains.

\section{B. Portugal \\ Sa-198. Salemas, Level III \\ $6320 \pm 350$ \\ 4370 в.c.}

Charcoal in reddish clay from a cave, Level III, Salemas $\left(38^{\circ} 56^{\prime} \mathrm{N}\right.$ Lat, $9^{\circ} 06^{\prime} \mathrm{W}$ Long) . Coll. 1960 and subm. 1962 by J. Roche, Lab. de Paléontologie de la Sorbonne, Paris. Comment: charcoal was collected by Geol. Survey of Portugal in Upper Paleolithic level. Following dating, which corresponded to Neolithic, J. Roche undertook a new examination of the level which showed that several burials had been dug during Neolithic period.

\section{Sa-199. Anta dos Tassos}

$3320 \pm 200$ 1370 в.c.

Charcoal from Megalithic burial site at Anta dos Tassos $\left(37^{\circ} 47^{\prime} \mathrm{N}\right.$ Lat, $8^{\circ} 27^{\prime}$ W Long). Coll. 1960 by O. da Veiga Ferreira; subm. 1962 by J. Roche. Comment: this grave was under a barrow, comprising a cupola and a circular crypt (Roche et al., 1964), similar to other burial sites of Eneolithic period of Los Millares (Santa Fe de Mondujar, Almeria, Spain). Site of Los Millares has been dated $4300 \pm 85$ B.P. by Munnich (Almagro, 1959). The Anta dos Tassos date shows that Megalithic period lasted at least $1000 \mathrm{yr}$ in $\mathrm{S}$ of Iberic Peninsula.

\section{Muge series}

Several shell heaps ("concheiros") are known on terraces near Muge River. According to geological considerations, human settlement of this region began after end of Wurmian period, and lasted through Paleolithic, Mesolithic, Neolithic, Bronze and Roman ages. These shell heaps contain many graves and abundant bone and lithic industry. Coll. and subm. 1963 by J. Roche.

\section{Sa-194. Cabeço da Amoreira, upper level}

$6050 \pm 300$

Charcoal in shell level at Cabeço da Amoreira (39 $04^{\prime} \mathrm{N} \mathrm{Lat,} 8^{\circ} 27^{\prime} \mathrm{W}$ Long). 
Sa-195. Cabeço da Amoreira, lower level

$7030 \pm 350$

5080 B.C.

Charcoal in sandy conglomerate level corresponding to first settling of site of Cabeço da Amoreira ( $39^{\circ} 04^{\prime} \mathrm{N}$ Lat, $8^{\circ} 27^{\prime} \mathrm{W}$ Long) .

Sa-196. Cabeço da Arruda, Ad. S.

$5150 \pm 300$

3200 в.с.

Charcoal from shell bed, upper level, at Cabeço da Arruda $\left(39^{\circ} 03^{\prime} \mathrm{N}\right.$ Lat, $8^{\circ} 28^{\prime}$ W Long).

\section{Sa-197. Cabeço da Arruda, Ad. m.}

$6430 \pm 300$

Charcoal from sandy lower level at Cabeço da Arruda $\left(39^{\circ} 03^{\prime} \mathrm{N}\right.$ Lat, $8^{\circ} 28^{\prime}$ W Long).

General Comment: the first Muge "concheiro" dated was that of Moita do Sebastiâo, $7350 \pm 350$ (Sa-16, Saclay I). Cabeço da Amoreira is $2 \mathrm{~km} \mathrm{SE}$; on opposite side of Muge River, $4.5 \mathrm{~km} \mathrm{NE}$, is Cabeço da Arruda. This first series of dates shows very long occupation on each of the latter two sites. Industry of these sites is trapezoïdal flint microliths, big quartzit tools, sandstone grinding stones and bone knives and piercers.

\section{Mauritania}

\section{Sa-219. Tedgaoust}

$$
\begin{array}{r}
150 \\
\text { A.D. } 1800
\end{array}
$$

Charcoal from Tedgaoust, $1.50 \mathrm{~m}$ depth in Pit 1 bis $\left(17^{\circ} \mathrm{N}\right.$ Lat, $12^{\circ} \mathrm{W}$ Long); coll. 1961 and subm. 1962 by J. Devisse, Univ. de Dakar, Fann, Dakar, Sénégal. Comment: expected date, Medieval. Sample is from presumed site of great ancient town of Aoudaghost, terminal S point of Berber caravans linking Mediterranean regions to Black Africa.

\section{Viet-Nam}

\section{Sa-205. Hang Gon}

$3950 \pm 250$

2000 B.c.

Charred greasy deposit on pottery fragments from archaeological site of Hang Gon, near Xuan Loc ( $10^{\circ} 48^{\prime} \mathrm{N}$ Lat, $107^{\circ} 15^{\prime} \mathrm{E}$ Long), NE of Saïgon. Coll. and subm. by E. Saurin, Faculté des Sci., Univ. de Saïgon, Viet-Nam. Comment: older than supposed. Pottery was accompanied by moulds for bronze axes, similar to those found in $\mathrm{N}$ of Indochina associated with Chinese weapons and money, dated $2000 \mathrm{yr}$ B.P. In fact, this type of axe was probably used earlier. Sample contained $3 \%$ of carbon.

\section{E. Chile \\ Sa-226. San Pedro de Atacama \\ $1700 \pm 150$ \\ A.D. 250}

Wood fragment from tree branch found in grave at San Pedro de Atacama $\left(22^{\circ} 55^{\prime} \mathrm{S}\right.$ Lat, $68^{\circ} 15^{\prime} \mathrm{W}$ Long). Coll. and subm. 1962 by Father G. Le Paige, Univ. Del Norte, San Pedro de Atacama, Chile. Comment: expected age 1500 B.P. Date confirms antiquity of Atacamian culture. Similar grave was already dated at San Pedro de Atacama: $1650 \pm 150$ B.P. (Sa-109, Saclay I). 
II. GEOLOGIC SAMPLES

A. France

\section{Sa-242. Jarrie, Isère}

Wood from Quaternary deposit at Jarrie, Isère $\left(45^{\circ} 06^{\prime} \mathrm{N}\right.$ Lat, $5^{\circ} 43^{\prime} \mathrm{E}$ Long, alt $250 \mathrm{~m}$ ), $15 \mathrm{~m}$ depth in alluvial deposits (sand and gravel) at junction of Drac and Romanche rivers. Coll. 1961 and subm. 1962 by R. Lichtenberger, Centre de Recherches de Lyon, Pierre-Bénite, Rhône. Comment: sample gives minimum age of Würm III glacier recession at that point.

\section{Saint Egrève series}

Wood samples from core boring, SE 51, at Saint-Egrève, near Grenoble, Isère $\left(45^{\circ} 15^{\prime} \mathrm{N}\right.$ Lat, $5^{\circ} 41^{\prime} \mathrm{E}$ Long), in sandy alluvial deposits of the Isère. Coll. 1961 and subm. 1962 by P. Bachy Co., Paris, Seine.

\section{Sa-220. Saint-Egrève, $30-33 \mathrm{~m} \quad 9500 \pm 400$ 7550 в.c. \\ Sa-221. Saint-Egrève, $37-38 \mathrm{~m}$ \\ $7300 \pm 350$ 5350 в.c.}

General Comment: site is $18 \mathrm{~km}$ down-stream from Jarrie site. Samples were dispersed in sand deposits. Sa-220 was probably deposited from a more ancient sediment situated up-stream and confirms comment of Sa-242. Corresponding level at Saint-Egrève site is probably much deeper than Sa-221 level and shows that sediments were very abundant in Isère valley after last great glacier thaw.

\section{Sa-207. Clermont-Ferrand, Puy de Dôme}

$900 \pm 120$

Peat mixed with clayey and sandy sediments from $1.70 \mathrm{~m}$ to $2.10 \mathrm{~m}$ depth at Clermont-Ferrand, quartier des Salins $\left(45^{\circ} 47^{\prime} \mathrm{N}\right.$ Lat, $3^{\circ} 05^{\prime} \mathrm{E}$ Long $)$. Coll. 1960 and subm. 1961 by L. Gachon, Station d'Agronomie, Clermont-Ferrand, Puy de Dôme. Comment: pollen study gives age between Roman period and Middle Ages. Date shows that site, situated on $\mathbb{W}$ side of Limagne plain, has been subjected, since Middle Ages, to a very abundant sedimentation.

\section{Sa-208. Lempdes, Puy de Dôme \\ $5400 \pm 300$ \\ 3450 в.c.}

Peat mixed with clayey sediments, $1.50 \mathrm{~m}$ to $1.55 \mathrm{~m}$ depth, under black soil and over a 20-cm layer of diatomite, Le Marmillat, Lempdes bog, Puy de Dôme ( $45^{\circ} 47^{\prime} \mathrm{N}$ Lat, $3^{\circ} 05^{\prime}$ E Long). Coll. and subm. 1961 by L. Gachon. Comment: sample dates marshy period following lacustrine period in this region and gives an absolute point on scale of postglacial pollen analysis in the Auvergne plain. It also gives maximum age of the beginning of formation of the black soils, the "terres noires de Limagne."

\section{Sa-103. Pont du Chateau, Puy de Dôme \\ $13,500 \pm 450$ \\ 11,650 в.с.}

Peat, at depth $14 \mathrm{~m}$, under sandy and pebbly alluvium, lying on Oligocene rocks in a terrace of Allier River, 1 km NE of Pont du Chateau, Puy de Dôme 
( $45^{\circ} 48^{\prime} \mathrm{N}$ Lat, $3^{\circ} 15^{\prime} \mathrm{E}$ Long). Coll. 1962 by A. Rudel; subm. 1962 by H. Pelletier, Chassignol Thiers, Puy de Dôme. Comment: mixed with sand and pebbles overlying the peat are numerous bones of Elephas primigenius, Ursus spelaeus, Cervus elaphus, Capra ibex, Equus caballus, Rhinoceros tichorinus, Felis leo race spelea, Rangifer tarandus, Bison priscus, dating from Würm, according to paleontologists (Rudel, 1953). Pollen analyses of the peat show Pinus, Betula, Picea, Ulmus, Ranunculus, Carya, Alnus, Artemisia, Plantago, Ephedra distachya. Simultaneity of fauna and flora of cold and warm climates is not yet explained.

\section{Sa-224. Penerf, Morbihan}

$780 \pm 100$

A.D. 1170

Shells of Patella, Ostrea, Mytilus, Littorina, from shell bed in clayey cliff, $2 \mathrm{~m}$ high, between Damgan and mouth of Penerf River $\left(47^{\circ} 32^{\prime} \mathrm{N}\right.$ Lat, $2^{\circ} 34^{\prime}$ W Long). Coll. and subm. 1962 by A. Rivière, Faculté des Sci. d'Orsay, Seine et Oise.

\section{Sa-225. Iles de Dindilles, Leucate Pool $\quad 2440 \pm 160$}

$\begin{aligned} 490 & \text { в.c. }\end{aligned}$ level, W coast of $\mathrm{N}$ Ile des Dindilles in Leucate Pool $\left(42^{\circ} 50^{\prime} \mathrm{N}\right.$ Lat, $3^{\circ} 05^{\prime} \mathrm{E}$ Long). These species of shells no longer live in the pool, but are still living elsewhere. Leucate pool is situated along $W$ coast of Mediterranean Sea, ca. $2 \mathrm{~km}$ from the coast. Coll. and subm. 1962 by $\mathrm{A}$. Rivière.

\section{Sa-223. Saint-Aubin-sur-Mer, Seine Maritime $\quad 3220 \pm 200$}

Wood taken in peat appearing on sea floor before beach of Saint-Aubinsur-Mer $\left(49^{\circ} 32^{\prime} \mathrm{N}\right.$ Lat, $0^{\circ} 53^{\prime} \mathrm{W}$ Long), uncovered at very low tide and 100 $\mathrm{m}$ distant from present sea shore. Coll. and subm. 1962 by E. Roth, Centre d'Etudes Nucléaires de Saclay, Seine et Oise. Comment: shows the minimum erosion speed of the coast in the Normandy chalk cliffs region: $150 \mathrm{~m}$ in 3200 $\mathrm{yr}(50 \mathrm{~m}$ is the mean width of the protecting dune behind which are the fens in this region).

\section{Bernières-sur-mer series, Calvados}

Submerged terrace, covered by peat, at Bernières-sur-Mer, Calvados ( $49^{\circ} 19^{\prime} 45^{\prime \prime} \mathrm{N}$ Lat, $2^{\circ} 45^{\prime} \mathrm{W}$ Long), $300 \mathrm{~m}$ from sea shore and $2.5 \mathrm{~m}$ above zero sealevel (chart datum). Coll. 1959 and subm. 1961 by P. Hommeril, Faculté des Sci. de Caen, Calvados.

\section{Sa-200. Bernières 61-1}

$$
\begin{aligned}
& 23,300 \pm 1000 \\
& 21,350 \text { в.c. }
\end{aligned}
$$

Layer, $2 \mathrm{~cm}$ thick, of calcareous shelly sandstone, at top of terrace. Comment: this calcareous sandstone is an agglomerate of large shells and finely ground shell fragments: total carbonate was used for measurement. Probably dates the last consolidation of the terrace and confirms the Normannien age expected.

\section{Sa-202. Bernières 61-3}

$3460 \pm 200$

$6 \mathrm{~cm}$ layer of clayey peat, above an $8 \mathrm{~cm}$ clayey level overlying the cal- 
careous sandstone. Comment: peat belongs to Flandrian transgression, in accordance with geological evidence.

\section{Mur de Sologne series, Loiret}

Peaty sediments from dried-up fen, near Mur de Sologne, S of the river Loire ( $47^{\circ} 25^{\prime} \mathrm{N}$ Lat, 36' E Long), overlying Miocene sands. Pollen-analyses of these peats were made by N. Planchais (unpub.). Coll. 1962 by N. Planchais; subm. 1963 by M. Van Campo, Mus. d'Histoire Naturelle, Paris. Depth in $\mathrm{cm}$ from the surface is given in each heading.

\section{Sa-234. Mur de Sologne, $150 \mathrm{~cm}$}

$1770 \pm 150$

Fibrous peat with pollen of Betula and Quercus, presence of Fagus and beginning of Ulmus; abundant cereal pollen.

\section{Sa-235. Mur de Sologne, $260 \mathrm{~cm}$}

$4420 \pm 250$

2470 в.c.

Peaty black mud; abundance of Pinus pollen, beginning of Quercus and end of Corylus indicate a boreal period.

\section{Sa-236. Mur de Sologne, $320 \mathrm{~cm}$}

Clayey peat, base of the peat overlying Miocene sand; corresponds to beginning of Quaternary sedimentation. In peat, abundant pollen of herbaceous plants.

General Comment: cereal pollen in $1770 \pm 150$ level indicate beginning of reclamation of land in Sologne which is historically correct. Two other levels are several thousand yr too young according to the boreal flora contained. This is probably due to present Phragmites rhizomes penetrating deeply into the peat.

\section{Sa-247. Prémery, Nièvre}

$7550 \pm 350$

\section{$\mathbf{5 6 0 0}$ B.C.}

Grey dry silt from bottom of a dip in karstic ground in forest of Prémery (47 $12^{\circ} \mathrm{N}$ Lat, $3^{\circ} 18^{\prime} \mathrm{E}$ Long). Coll. 1962 by N. Planchais; subm. 1963 by M. Van Campo. Comment: pollen of Pinus, Ulmus, and Quercus, and abundance of Corylus indicate a boreal period in agreement with age found.

\section{Bou Ali series, Touat}

\section{B. Sahara}

Study of a section cut by a "oued" in a Quaternary formation at Bou Ali, Touat $\left(27^{\circ} 10^{\prime} \mathrm{N}\right.$ Lat, $0^{\circ} 15^{\prime} \mathrm{W}$ Long). Deposit forms a terrace, $5 \mathrm{~m}$ high, composed of boggy paleosols with Phragmites and Typha, separated by calcareous tufas and sand layers. Coll. 1960 and subm. 1961 by G. Conrad, Centre de Recherches sur les zones arides, Paris.

\section{Sa-211. Level 444}

$1520 \pm 150$

Second black level from bottom in terrace.

A.D. 430

modern

Sa-212. Level 445

Third black level in terrace. 
Sa-212 bis. Level 446

modern

Fourth black level in terrace.

General Comment: shows the persistence of moist conditions until a recent period in the Occidental Sahara (Conrad, 1963). Level 445 is ca. $2.5 \mathrm{~m}$ under the present surface and shows that accumulation of overlying sand and tufas has been very fast.

\section{Saoura terrace series}

Samples of lacustrine paleosols from sedimentary levels in late-Quaternary terraces of the Saoura Oued (N.W Sahara). Coll. 1959 and subm. 1961 by G. Conrad.

\section{Sa-210. Beni Abbès, n'barra 210}

$\mathbf{5 6 1 0} \pm \mathbf{3 2 0}$

$\mathbf{3 6 6 0}$ B.c.

Lacustrine paleosol, $10 \mathrm{~cm}$ thick, underlying layer of white sandy marl, $30 \mathrm{~cm}$ thick, near Beni Abbès $\left(30^{\circ} 8^{\prime} \mathrm{N}\right.$ Lat, $2^{\circ} 6^{\prime} \mathrm{W}$ Long), and lying on oldest Quaternary formation of the terrace. Comment: expected age 20,000 or 30,000 B.P.

\section{Sa-217. Beni Abbès 249}

$6160 \pm 300$

4210 B.c.

Alluvial paleosol without limestone, $30 \mathrm{~cm}$ thick, under present sand and gravels, near Beni Abbès ( $30^{\circ} 7^{\prime} \mathrm{N}$ Lat, $2^{\circ} 6^{\prime} \mathrm{W}$ Long), and lying on an erosion level of the terrace. Comment: age Neolithic, as expected. Organic fraction, extracted for dating, was about $1 \%$ of the sediment. Palynologic study shows a renewal of humid conditions: northern species are associated with typical Saharan forms (Ephedra and Chenopodiaceae) (Conrad, 1963).

\section{Sa-216. Bou Hadid E. 10}

$20,200 \pm 1000$ 18,250 в.с.

Lignite from $8.60 \mathrm{~m}$ to $8.80 \mathrm{~m}$ depth, at Bou Hadid $\left(29^{\circ} 52^{\prime} \mathrm{N}\right.$ Lat, $1^{\circ} 50^{\prime}$ W Long), included in green-grey sands of lower levels of the terrace. Comment: pollen analysis indicated Pinus, Quercus, Tilia, Alnus, Salix $(5$ to $6 \%$ only), Artemisia and abundance of Gramineae, rare Ephedra. $\mathrm{C}^{14}$ date makes sample synchronous with oldest level dated in E Niger for the lacustrine period (Faure et al., 1963) 21,350 B.P. (T-340 B, Trondheim IV). Also dates the Acheulean industry found in place in lower levels of the terrace.

General Comment: Sa-210 and Sa-217 show a humid climate in the Neolithic period for low altitude regions in northern Sahara, as already found in mountainous regions of Hoggar, Adrar Bous, Tassili (Sa-59, Sa-62, Sa-66, Sa-100, Saclay I). Sa-216 shows that the great "pluvial" period of the Sahara was contemporaneous with glacial period in Europe.

\section{Sa-233. Galicia, K-15}

$$
\text { C. Spain }
$$

$$
\begin{aligned}
& 13,600 \pm 450 \\
& 11,650 \text { в.c. }
\end{aligned}
$$

Organic remains from sediment in humic peaty clay, at upper level of peaty deposit covered by torrential remains near Burela, Galicia $\left(43^{\circ} 40^{\prime} \mathrm{N}\right.$ Lat, $7^{\circ} 21^{\prime}$ W Long). Coll. by M. Nonn 1962; subm. 1963 by M. Van Campo. 
Comment: very abundant pollen of Gramineae and abundant Pinus silvestris indicate very cold climate and correspond to Würm III (Delibrias et al., 1964).

\section{Lebanon}

\section{Sa-209. Mont Sannin}

$1540 \pm 150$

Cedar wood, near the top of Mont Sannin $2620 \mathrm{~m}$ high $\left(35^{\circ} 54^{\prime}\right.$ E Long, $33^{\circ} 57^{\prime} \mathrm{N}$ Lat). Found after landslip during snow thaw under clayey calcareous deposits. Subm. 1961 by Malik Babous, Directeur du Département des Forêts du Gouvernement Libanais, Beyrouth, Liban. Comment: probably a remnant of the famous old cedar forest of Lebanon. Cedrus libani is now very scarce in Lebanon.

\section{Sa-229. Ferpècle}

E. Switzerland

$4030 \pm 250$

2080 в.c.

Wood of Pinus Cembra cast up by glacier of Ferpècle in Switzerland (46 $03^{\circ} \mathrm{N}$ Lat, $7^{\circ} 33^{\prime} \mathrm{E}$ Long). Coll. 1961 by J. Martin at junction of the Ferpècle and Mont Miné glaciers; subm. 1962 by P. Bellair, Faculté des Sci. de Paris. Comment: age corresponds to end of "climatic optimum," when Alpine glaciers disappeared almost entirely; the permanent snow level was 300 or $500 \mathrm{~m}$ higher than at present.

\section{F. Greece \\ Sa-241. Crete \\ $4500 \pm 300$ \\ 2550 в.C.}

Charcoal powder mixed with ashes from hearth in cave closed by earthquake, on Crete $\left(35^{\circ} 23^{\prime} \mathrm{N}\right.$ Lat, $24^{\circ} 07^{\prime} \mathrm{E}$ Long $)$; charcoal was covered by a fine deposit of calcite. Coll. 1961 and subm. 1963 by P. Faure, Ecole Française d'Archéologie, Athènes, Grèce. Comment: fragments of pottery found around the hearth were archaeologically dated as late Neolithic. $\mathrm{C}^{14}$ age agrees well with this expectation and dates the quake which closed the cave. Furthermore, presence of calcite in cave confirms a subsequent period of greater rainfall in Crete (Faure, 1964). The formation of lakes in caves in Cyrenaïca and in Syria at that time has already been mentioned (Butzer, 1958).

\section{G. Cambodia}

\section{Sa-237. Tonle-Sap lake, Ge 11 \\ $\mathbf{5 7 2 0} \pm \mathbf{3 0 0}$ \\ 3770 в.с.}

Wood from clayey sediment from central part of the great lake Tonle-Sap ( $12^{\circ} 49^{\prime} \mathrm{N} \mathrm{Lat,} 104^{\circ} 05^{\prime} \mathrm{E}$ Long), $1.80 \mathrm{~m}$ depth in the sediment, at bottom of the "modern" silt layer; lying on a fine sandy deposit, $10 \mathrm{~cm}$ thick, which in turn overlies the "old" silt. Coll. and subm. 1962 by P. Carbonnel, Lab. de Géog. Physique, Univ. de Paris. Comment: dates beginning of formation of modern sediment and of modern lake; the mean thickness of the sediment being $1.50 \mathrm{~m}$, a mean sedimentation rate of $35 \mathrm{~cm}$ per $1000 \mathrm{yr}$ can be calculated for the whole lake. Lateritisation of the top of the ancient silt shows that a dry period, during which lake was non-existent, occurred previously. Present level of lake is $0.8 \mathrm{~m}$ above mean sealevel. Intermediate sand layer may be con- 
temporary with Flandrian transgression, completion of which would have contributed to formation of the lake (Carbonnel, 1964). Marine terraces of Flandrian age are known at $\mathrm{Ca} \mathrm{Na}$ (S Viet-Nam): MC-2, $4500 \pm 250$; Monaco I.

\section{H. Japan}

\section{Sa-243. Nukumi, Kyushu}

$8620 \pm 350$

6670 B.c.

Islond $40 \mathrm{~m}$ thick, at Nukumi, Kyushu Island $\left(32^{\circ} 33^{\prime} \mathrm{N}\right.$ Lat, $131^{\circ} 28^{\prime} \mathrm{E}$ Long). Coll. and subm. 1962 by H. Tazieff, Centre Européen de Vulcanologie, Bruxelles. Comment: dates an enormous eruption, probably connected with formation of the big caldera of Ata.

\section{Sa-244. Osaru, Hokkaido}

$11,520 \pm 400$

Charcoal under tuff, near Osaru, $10 \mathrm{~km}$ SE of volcano Usu-San, Hokkaido Island $\left(42^{\circ} 30^{\prime} \mathrm{N}\right.$ Lat, $140^{\circ} 58^{\prime} \mathrm{E}$ Long). Coll. and subm. 1962 by H. Tazieff. Comment: this deposit is contemporary with formation of the caldera of Toya (diam $10 \mathrm{~km}$ ); on $\mathrm{S}$ side of this caldera was a remarkable activity characterized by extrusion of the Pelean hills of Usu and Showa-Shinzan.

Date lists:

\section{REFERENCES}

Michigan V Crane and Griffin, 1960

Monaco I Thommeret and Rapaire, 1964

Saclay I

Delibrias et al., 1964

Trondheim IV Nydal, 1964

Almagro, M., 1959, La primera fecha absoluta para la cultura de Los Millares a base del Carbono 14: Ampurios, v. 21, p. 249-25l.

Butzer, K. W., 1958, Quaternary stratigraphy and climate in the Near East: Bonner Geographishe Abhandlungen, no. 24, p. 110-116.

Carbonnel, J. P., 1964, Vitesse d'accumulation des sédiments récents du grand lac du Cambodge d'après le C-14. Corrélations stratigraphique et morphotectonique: Compte rendu à l'Acad. des Sci. de Paris, in press.

Conrad, G., 1963, Synchronisme du dernier pluvial dans le Sahara septentrional et le Sahara méridional: Compte rendu à l'Acad. des Sci. de Paris, v. 257, p. 2506-2509.

Dangeard, L., Hommeril, P., 1964, Le grès calcaire normannien de Bernières-sur-Mer (Calvados) et les dépôts associés. Datation au carbone 14: Compte rendu sommaire des séances de la Société Géologique de France, 1964, fascicule 3, p. 126.

Delibrias, G., Nonn, H., Van Campo M., 1964, Age et flore d'un dépôt périglaciaire reposant sur la "rasa" cantabrique prés de Burela (Galicie), Espagne: Comptes Rendus de l'Acad. des Sci., v. 259, p. 4092-4094.

Faure, H., Manguin, E., Nydal, R., 1963, Formations lacustres du Quaternaire supérieur du Niger oriental: diatomites et âges absolus: Bull. Bureau de Recherches Géologiques et
Miniéres, no. 3, p. 41 .

Faure, P., 1964, Fonctions des cavernes crétoises: Thèse, Univ. de Paris, de Boccard Ed.

Gachon, L., 1961, L'évolution paléobotanique de la Limagne d'Auvergne au cours du Postglaciaire: Compte rendu à l'Acad. des Sci. de Paris, v. 253, p. 174-175.

Roche, J., Delibrias, G., 1964, Datation d'un monument énéolithique du Bas-Alentejo (Portugal) par la méthode du carbone 14: Revue archéologique, in press.

Rudel, A., 1953, La faune quaternaire des terrasses de l'Allier à Pont du Chateau: Revue des Sci. Naturelles d'Auvergne, Nouvelle Série, fascicule 1-2. 